Business and Economics Research Journal

Volume 9 Number 12018

pp. $1-13$

ISSN: $1309-2448$

DOI Number: 10.20409/berj.2018.90

\title{
Impact of Foreign Direct Investment on Human Development Index in Nigeria
}

\author{
Korhan K. Gökmenoğlu ${ }^{\mathrm{a}}$
}

Martins Olugbenga Apinran ${ }^{\mathrm{b}}$

Nigar Taşpınar ${ }^{c}$

\begin{abstract}
Economic growth is a necessary condition for human progress, but not sufficient in itself to guarantee it; therefore, other dimensions and determinants of human development must be investigated by researchers. This paper explores the impact of foreign direct investment (FDI) on the human development index (HDI) in Nigeria for the period of 1972-2013. Johansen cointegration test results reveal a long-term relationship between FDI and human development indices (e.g., school enrollment, life expectancy at birth, and gross national income). Toda-Yamamoto test results show long-run bidirectional causality between FDI and life expectancy at birth. There is also unidirectional causality from FDI to gross national income. These results indicate that FDI has a significant impact on the HDI in Nigeria during the sample period. The striking message our empirical findings conveys is that the effect of FDI on the HDI is a complicated issue, so to obtain optimum results policy-makers should be aware of and take into account the pros and cons of FDI inflows on several aspects of human development.
\end{abstract}

Keywords: Foreign direct investment, Human development index, Cointegration, Toda-Yamamoto, Nigeria

JEL Classification: F40, C01, 015

\section{Introduction}

Conventional logic broadly assumes that human development is almost a linear function of economic growth. Nevertheless, this assumption has been investigated by many researchers (Pyatt, 1987; Escobar, 2000) and international organizations including the United Nations Development Program (UNDP) (1999) for the last several decades. Among many others, Sen (1995) attacked conventional wisdom in his pioneering research on the relationship between economic growth and overall welfare. Sen (1995) made cross-country comparisons and found that China and Sri Lanka had a much lower gross national product (GNP) per capita, but life expectancy in these countries was considerably higher when it was compared to South Africa, Brazil, and Gabon in 1992. Therefore, he suggested that economic growth is a necessary but no longer sufficient condition to improve the overall welfare of a country. Stiglitz (2006) in accordance with the findings of Sen (1995) claims that as a result of narrow focus on GDP, other vital factors of development such as education and health can be overlooked.

Economic growth is one of the main determinants of human well-being. Therefore, sustainable high economic growth has been one of the main objectives of policymakers all around the world. However,

aPh.D., Eastern Mediterranean University, Banking and Finance Department, North Cyprus via Mersin, Turkiye, korhan.gokmenoglu@emu.edu.tr (ORCID ID: 0000-0002-2013-6867)

${ }^{b}$ Eastern Mediterranean University, Economics Department, North Cyprus via Mersin, Turkiye, gbengamartins699@yahoo.com

cPh.D., Eastern Mediterranean University, Banking and Finance Department, North Cyprus via Mersin, Turkiye, nigar.taspinar@emu.edu.tr (ORCID ID: 0000-0003-3012-4920) 
economic growth, despite being a necessary condition for human progress, is not a sufficient condition and has not guaranteed desirable development in the human condition globally. Economic growth can be measured by the gross domestic product (GDP) but results in a one-segment measurement within the multifaceted dimensions of real development and is too narrow a measure of human development in general. Thus, using only the GDP to measure well-being might be misleading (Krugman, 1995). Given the inadequacy of the GDP, a broader analytical approach that captures every aspect and different dimensions of human well-being (welfare) and includes other physical and social indicators of quality of living and liberty such as standard of living, affordable and accessible health facilities, and access to state-of-the-art medical knowledge is needed.

The long debate among economists and policymakers on finding a more definitive indicator of economic and societal progress of countries resulted in the development of new measures and indexes. The human development index (HDI), developed by the United Nations Development Programme (UNDP) (1999), measures the standard of living and provides a useful tool for comparative evaluations of nations in terms of several indicators including education, literacy, average life expectancy (LE), and life quality. The HDI has gained tremendous global recognition among academicians and policymakers as an established rating tool since the 1990s (Streeten, 1999; Ranis et al., 2000). The indices have been published in the annual Human Development Report prepared under the management of the UNDP (1999). Foreign direct investment (FDI) is another intensely debated concept in macroeconomics. Albeit the origin of the debate goes too far back, following Vermon's (1966) product cycle theory, academic interest in the importance of FDI reemerged $^{1}$. Internalization theory (Buckley, 1985), the eclectic paradigm (Dunning, 1979), and the theory of competitive advantage (Porter, 1990) are early examples of significant contributions to the academic discussion and constitute the theoretical base for the importance of FDI. With the help of intensifying globalization and elaborated theoretical background, FDI has increased substantially over the last several decades. Even the perceived threat of FDI to the sovereignty of host nations has not been sufficient to hinder the incentive of developing countries to attract multinational enterprises (MNEs). Thus, these developments have led to a rapid growth of FDI inflow especially to the developing world (United Nations Conference on Trade and Development (UNCTAD), 2011). The growing importance of FDI has resulted in numerous empirical studies investigating the impact of FDI on the economy.

Owing to the its magnitude and growing importance, the effect of FDI on many other variables including knowledge and skills (Hansen and Rand, 2006), competitiveness of domestic firms (Sun and He, 2014), productivity (Ericsson and Irandoust, 2001; Khawar, 2003), technological development (Kemeni, 2010), domestic investment (Agosin, 2005; Al.Sadiq, 2013), and stock values (Huang and Shiu, 2009); has been investigated extensively. Since technology, capital, and management expertise are bundled together in FDI, it has significant implications for economic progress and the welfare of recipient nations. Many papers in the literature have explored this issue with specific attention to economic development (AnumMohdGhazali, 2010) and economic growth (Neto et al., 2008; Chang, 2010). The majority found that FDI has a progressive impact on the economic growth of both developed and developing countries ${ }^{2}$ (Omri, 2014; Belloumi, 2014; lamsiraroj \& Ulubasoglu, 2015). Given the importance of FDI to the overall macroeconomic fundamentals, including economic growth, FDI is expected to affect human development directly or indirectly. Additional revenue, capital, and employment have direct bearing on FDI in the host nations and can indirectly affect welfare via industrial structure, human capital, and technological spillovers. In that respect, the primary question of this paper is whether FDI significantly stimulates the broadly defined measure of human development and welfare.

In response to this question, the available literature should be expanded to accommodate an analysis of the overall impact on welfare of FDI beyond its effect on economic growth. It should capture the progress of education, life expectancy at birth, impact of technology as well as the macroeconomic environment of the recipient nations. The rising concern surrounding the global financial crisis, food crisis, and ongoing social unrest in many developing economies evident in the increasing costs of food and energy, social justice, and lack of civil liberties has made the association between FDI and social welfare more significant and timely in this era. 
The Millennium Development Goals (MDGs) report of World Bank shows that in terms of fight with the poverty, the performance of Africa is worse than the other regions of the world (World Bank, 2015). Economic growth is the most important tool to fight against poverty. In order enhance economic growth and decrease poverty African countries have been seeking for FDI by the help of several initiatives one of the most important of which is the New Partnership for Africa's Development (NEPAD). The corporate Nigeria reports (2010) that Nigeria is the leader country in term of FDI inflow. So, FDI is especially important for Nigerian economy. There are many studies about the determinants of FDI for the case of Nigeria (Salako, \& Adebusuyi, 2001). Although, there are some studies on the effect of FDI on economic growth of Nigeria (Imoudu, E. C. (2012), they are limited (Didia, Freeman, Assad, \& Yuan, 2015). Also, to our best knowledge, there is no study on the relationship between FDI and human development for the case of Nigeria. Hence, the relationship between FDI, economic growth and human development is not clear (Inekwe, 2013) and needs further investigation. Our study aims to develop a comprehensive understanding by taking into account both economic growth and human development factors about the effect of FDI on the well-being of Nigeria people.

This study empirically investigates the effect of FDI on the advancement of the host nations' social welfare. The aim of this study is to investigate the long-run relationship between indicators of HDI which are life expectancy at birth (LE), school enrollment (SE) and gross national income (GNI), and FDI in Nigeria which has been neglected by the previous literature. To this aim, Johansen (1988) co-integration test, dynamic ordinary least squares (DOLS) for long-run coefficient estimations and Toda-Yamamoto (1995) long-run causality test are employed for the period of 1972 - 2013.

The paper includes five sections. This section is followed by the literature review, data and methodology, empirical findings, and the conclusion subsequently.

\section{Literature Review}

As with many other important concepts, it is not easy to define the concept of "welfare" in a way that captures all its components, including macroeconomic impact, social phenomena, and the natural atmosphere. The relationship between FDI and human development is addressed in the literature on welfare and economic growth. Sen's $(1987,1997,1998)$ studies regarding welfare economics place more emphasis on economic and societal parameters other than GDP growth, which represents a paradigm shift in the process of measuring the overall advancement in the quality of life of an individual. Sen (1992) affirms that "while economic analysis has often centered on income and goods to evaluate a person's benefit, misery, and deprivation, there is a need to shift attention to things that people have reasons to value intrinsically."

One of the main arguments in favor of FDI is its positive effect on economic growth. That being said, while a majority of researchers find evidence for FDI-led growth hypotheses-meaning that FDI contributes to the growth rate of the host country(Evans, 2002; Umoh, Jacob \& Chuku, 2012; Neto \& Veiga, 2013) -there are also some controversial findings claiming that FDI is detrimental to economic growth (Li \& Liu, 2005; Shaikh, 2010). However, the third group of studies has failed to find any relationship, either negative or positive, between these two variables (Chowdhury \& Mavrotas, 2006). These contradictory results imply that the relationship between FDI and economic growth is prone to be affected by mitigating factors, such as human capital, corruption (Acemoglu et al., 2005), complementarity of FDI and domestic investment (De Mello, 1999), the export-promoting strategies of the host country (Balasubramanyam et al., 1996), and financial and institutional developments (Durhan, 2004). When these factors are considered, the effect of FDI on economic growth becomes a controversial issue (Omri et al., 2014). The main lesson of the literature should be that the effect of FDI on the host country's economic capacity should never be overemphasized (OECD, 2007).

It is widely accepted that economic growth makes a positive contribution to human development. If this assumption is correct, then it can be expected that FDI has an indirect effect on human development via its relationship to economic growth. However, the assumption of a perfect positive relationship between economic growth and welfare has been criticized (e.g., Anand \& Sen, 2000).Bruno, Ravallion, and Squire 
(1996) claim that economic growth benefits all layers of society, but cannot automatically reduce income inequality. The effect of income growth on income inequality is related to the initial state of inequality in the country. For countries that have high level of inequality, economic growth might even increase the level of poverty and make human development worse (Gohou \& Soumaré, 2012). If economic growth is not pro-poor and does not encourage redistribution of wealth within a society, it may make the inequality worse and negatively impact welfare (Ravallion, 2007).

Compared with studies on the relationship between FDI and economic growth, studies devoted to examining the impact of FDI on human development are relatively scarce. However, for the last decade, the literature on the latter has been growing fast as a result of a paradigm shift declaring that the ultimate aim of investment policies should be to improve human development. Arcelus, Sharma, and Srinivasan (2004) scrutinize the effect of FDI on human development using the HDI scores for both middle- and low-income countries. For the sample period of 1975-1999, they find that FDI has positive and significant impact on human development for both groups of countries. Srinivasan (2005) examines the effect of foreign capital flow on the three ingredients of $\mathrm{HDI}$-wealth, life expectancy, and educational attainment-and finds that the effect of foreign capital on human development depends on several factors, the most important of which is returns to scale. Gohoun and Soumare (2012) investigate the impact of FDI on poverty reduction, which is an important determinant of human development, for the 1990-2007 period in five African regions by using FDI net inflow and HDI of UNDP as main variables. Their results provide evidence for a positive and significant relationship between FDI and poverty reduction. Also, they report that the effect of FDI inflow on poverty reduction is the strongest for poorer regions ${ }^{3}$.

Osenwengie and Sede (2013) critically explore the support of FDI in Nigeria to poverty reduction between 1981 and 2010 by employing cointegration and a vector error correction mechanism. They adopt $\mathrm{HDI}$ and life expectancy at birth as proxies for poverty alleviation in two separate models. Their results not only record both a long- and short-run relationship between FDI and poverty reduction, but also FDI's contribution to poverty alleviation in Nigeria in the year under review.

\section{Data and Methodology}

The data used in this study are annual figures that cover the period of 1972-2013. Figures for foreign direct investment inflows (measured as percentage of GDP) and indicators of the human development index, i.e. life expectancy at birth, school enrollment, and gross national income per capita are collected from World Bank development indicators (2015).

The functional relationship between human development indicators and FDI can be represented as follows;

$$
\begin{aligned}
& \ln L E_{t}=\beta_{0}+\beta_{1} \ln F D I_{t}+\varepsilon_{t} \\
& \ln S E_{t}=\beta_{0}+\beta_{1} \ln F D I_{t}+\varepsilon_{t} \\
& \ln G N I_{t}=\beta_{0}+\beta_{1} \ln F D I_{t}+\varepsilon_{t}
\end{aligned}
$$

where $\ln L E_{t}, \ln S E_{t}, \ln G N I_{t}$ and $\ln F D I_{t}$ are the logarithmic forms of life expectancy at birth, school enrollment, gross national income per capita, and foreign direct investment, respectively. We use logarithmic form of the variables in order to estimate elasticity which is preferable for comparison purpose.

The effect of FDI on economic growth has been studied extensively especially for developing countries. On the one hand, empirical studies provide mixed results on the effect of FDI on economic growth (Alfaro, Chanda, Kalemli, \& Sayek, 2004). On the other hand, it is well documented that FDI has positive effects on many important variables, such as market access, export quality, technology transfer and productivity (Amighini, \& Sanfilippo, 2014; Lall \& Narula, 2004), those can enhance economic growth. Hence, we expect to find a positive relationship between FDI and economic growth. The relationship between FDI, school 
enrollment and life expectancy hasn't studied enough empirically. Sede and Ohemeng (2015) found that conventional macroeconomic measure does not affect life expectancy for the case of Nigeria because of inefficient use of available resources (Sede \& Ohemeng, 2012). Following the above explanations which have been shared by many other researchers as well, we expect that FDI may not contribute to the life expectancy for the case of Nigeria. As mentioned before the effect of FDI on school enrollment in Nigeria hasn't been studied before. However, there are findings those show that economic factors are among the major determinants of school enrollment (Dostie \& Jayaraman, 2006). So, we expect a positive relationship between FDI and school enrollment.

\subsection{Unit Root Test}

The Augmented Dickey-Fuller (ADF) (Dickey \&Fuller, 1981) and Phillips-Perron (PP)(Phillips \&Perron, 1988) unit root tests are conducted to test the order of integration of the variables. The ADF test is applied in order to eliminate the possibility of rejecting a correct null hypothesis incorrectly. The PP procedures compute a residual variance that is robust to autocorrelation; it is commonly used to test for nonstationarity of variables as an alternative to the ADF unit root test.

\subsection{Cointegration Test}

After revealing the order of integration levels of variables, possible cointegration among variables should be tested. The aim of applying cointegration test is to investigate the long run equilibrium relationship among variables. The trace test of the Johansen approach is applied to test the cointegration among variables, which suggests that variables should be in the same order of integration, I(1) or I(2) if they are not stationary at their level forms. The null hypothesis for the trace test is that number of cointegrating vectors is less than or equal to zero, one and two, respectively. The null hypothesis is tested against an alternative for each case in order to estimate the number of cointegrating vectors in the conducted model.

The approach developed by Johansen (1988) and Johansen and Juselius (1990) is commonly used to avoid the problems which arise from Engel and Granger's (1987) methodology ${ }^{4}$, allowing us to investigate a cointegrating relationship among the independent variables and a dependent variable. Johansen cointegration test is one of the most reliable techniques when it is compared to alternative techniques for small samples. The existence of cointegration among variables eliminates the possibility of spurious correlation. That's why, prior to the estimation of long-run coefficients, the existence of cointegration among variables should be revealed.

\subsection{Estimation of Long-Run Coefficients}

After confirming the long-run equilibrium relationship between variables by the Johansen (1988) cointegration test, long-run coefficients are estimated by the dynamic ordinary least squares (DOLS) estimation technique which is developed by Stock and Watson (1993). The DOLS approach can be applied regardless of the integration levels of the independent variables, but the dependent variable of the model should be stationary at its first difference, $/(1)$. The reason for adopting DOLS estimation technique is that it is a superior technique in estimation of long-run coefficients for small samples when it is compared to alternative techniques as it is based on Monte Carlo simulations. Moreover, the advantage of the DOLS estimation technique is that it eliminates internality and autocorrelation problems in estimating the long-run values of coefficients (Stock and Watson, 1993). The DOLS models can be estimated as follows;

$$
\begin{aligned}
& \ln L E_{t}=\beta_{0}+\beta_{1} \operatorname{lnFDI}_{t}+\sum_{i=-q}^{q} \gamma_{i} \Delta \ln F D I_{t-i}+\varepsilon_{t} \\
& \ln S E_{t}=\beta_{0}+\beta_{1} \ln F D I_{t}+\sum_{i=-q}^{q} \gamma_{i} \Delta \ln F D I_{t-i}+\varepsilon_{t} \\
& \ln G N I_{t}=\beta_{0}+\beta_{1} \operatorname{lnFDI}_{t}+\sum_{i=-q}^{q} \gamma_{i} \Delta \ln F D I_{t-i}+\varepsilon_{t}
\end{aligned}
$$

Where $q$ indicates optimum lag level as determined by Schwarz information criterion. 


\subsection{Causality Test}

The Toda-Yamamoto (1995) causality test is applied in order to estimate the existence and direction of causality between variables. Toda-Yamamoto causality test requires the estimation of an augmented VAR to ensure the asymptotic distribution of Wald statistics. The Toda-Yamamoto (1995) test has several superior features. One of the major advantages of the Toda-Yamamoto test is that it is applied regardless of the integration order of the variables and cointegration properties of the models. Toda and Yamamoto (1995) suggest employing a Modified Wald stat (MWALD) to estimate the causal relationship among series. In this method, VAR $\left(k+d_{\max }\right)$ is estimated where $k$ is the optimal order of VAR model and $d_{\max }$ is the maximum order of integration. There are two steps to adopt the Toda-Yamamoto procedure. The first one is to determine the optimal lag length and the second step is to determine the level of the maximum order of integration for the variables. In this study, a bootstrap test is performed with endogenous lag order developed by Hacker and Hatemi-J (2010); the bootstrapped critical values are calculated with 10,000 simulations. Hacker and Hatemi-J's (2001) information criteria are applied for the optimal lag selection in the model.

$\operatorname{VAR}\left(k+d_{\max }\right)$ models can be estimated as follows;

$$
\begin{aligned}
& \ln L E=\alpha_{0}+\sum_{i=1}^{k} \alpha_{1 i} \ln L E_{t-i}+\sum_{j=k+1}^{d_{\max }} \alpha_{2 j} \ln L E_{t-j}+\sum_{i=1}^{k} \beta_{1 i} \ln F D I_{t-i}+\sum_{j=k+1}^{d_{\max }} \beta_{2 j} \ln F D I_{t-j}+\varepsilon_{1 t} \\
& \operatorname{lnFDI}=\alpha_{0}+\sum_{i=1}^{k} \alpha_{1 i} \operatorname{lnFDI}_{t-i}+\sum_{j=k+1}^{d_{\max }} \alpha_{2 j} \ln F D I_{t-j}+\sum_{i=1}^{k} \beta_{1 i} \ln L E_{t-i}+\sum_{j=k+1}^{d_{\max }} \beta_{2 j} \ln L E_{t-j}+\varepsilon_{2 t} \\
& \operatorname{lnSE}=\alpha_{0}+\sum_{i=1}^{k} \alpha_{1 i} \ln S E_{t-i}+\sum_{j=k+1}^{d_{\max }} \alpha_{2 j} \ln S E_{t-j}+\sum_{i=1}^{k} \beta_{1 i} \operatorname{lnFDI_{t-i}}+\sum_{j=k+1}^{d_{\max }} \beta_{2 j} \ln F D I_{t-j}+\varepsilon_{1 t} \\
& \operatorname{lnFDI}=\alpha_{0}+\sum_{i=1}^{k} \alpha_{1 i} \operatorname{lnFDI}_{t-i}+\sum_{j=k+1}^{d_{\max }} \alpha_{2 j} \operatorname{lnFDI_{t-j}}+\sum_{i=1}^{k} \beta_{1 i} \operatorname{lnS} E_{t-i}+\sum_{j=k+1}^{d_{\max }} \beta_{2 j} \operatorname{lnSE} E_{t-j}+\varepsilon_{2 t} \\
& \ln G N I=\alpha_{0}+\sum_{i=1}^{k} \alpha_{1 i} \operatorname{lnGNI}_{t-i}+\sum_{j=k+1}^{d_{\max }} \alpha_{2 j} \operatorname{lnGNI_{t-j}}+\sum_{i=1}^{k} \beta_{1 i} \ln F D I_{t-i}+\sum_{j=k+1}^{d_{\max }} \beta_{2 j} \ln F D I_{t-j}+\varepsilon_{1 t} \\
& \ln F D I=\alpha_{0}+\sum_{i=1}^{k} \alpha_{1 i} \ln F D I_{t-i}+\sum_{j=k+1}^{d_{\max }} \alpha_{2 j} \ln F D I_{t-j}+\sum_{i=1}^{k} \beta_{1 i} \ln G N I_{t-i}+\sum_{j=k+1}^{d_{\max }} \beta_{2 j} \ln G N I_{t-j}+\varepsilon_{2 t}
\end{aligned}
$$

\section{Empirical Findings}

Table 1 shows the results of the ADF and PP unit root tests. According to the ADF and PP unit root test results, all of the variables are not stationary at their level forms, which means the null hypothesis of non-stationarity cannot be rejected at level forms of the variables. Variables become stationary when the first differences are taken and said to be integrated of order one, I(1). Therefore, the long-run equilibrium relationship between the variables conducted in the study is investigated using the Johansen (1988) cointegration test. 
Table 1. ADF and PP Unit Root Tests

\begin{tabular}{|c|c|c|c|c|c|c|c|c|}
\hline $\begin{array}{l}\text { Statistics } \\
\text { (Level) }\end{array}$ & In SE & Lag & In LE & lag & In FDI & lag & In GNI & lag \\
\hline$\tau_{\mathrm{T}}(\mathrm{ADF})$ & -2.403 & (0) & -0.510 & $(2)$ & -1.671 & (1) & -1.930 & (0) \\
\hline$\tau_{\mu}(\mathrm{ADF})$ & -2.689 & (0) & 1.983 & (3) & -1.564 & (1) & 0.351 & (0) \\
\hline$\tau(\mathrm{ADF})$ & 0.574 & (0) & 1.075 & (3) & -1.231 & (1) & 5.724 & (0) \\
\hline$\tau_{\mathrm{T}}(\mathrm{PP})$ & -2.481 & (2) & -1.324 & (5) & -3.188 & (2) & -1.984 & (2) \\
\hline$\tau_{\mu}(\mathrm{PP})$ & -2.734 & (1) & -0.287 & (5) & -2.756 & (2) & 0.437 & (5) \\
\hline$\tau(\mathrm{PP})$ & 0.502 & (1) & 3.313 & $(5)$ & 1.725 & (3) & 6.182 & (5) \\
\hline $\begin{array}{l}\text { Statistics } \\
\text { (First } \\
\text { Difference) }\end{array}$ & $\Delta \ln \mathrm{SE}$ & lag & $\Delta \ln \mathrm{LE}$ & lag & $\Delta \mathrm{ln} F D I$ & lag & $\Delta \ln \mathrm{GNI}$ & lag \\
\hline$\tau_{\top}(\mathrm{ADF})$ & $-5.994^{* * *}$ & (0) & $-5.607^{* * *}$ & (2) & $-10.89^{* * *}$ & (2) & $-6.25^{* * *}$ & (0) \\
\hline$\tau_{\mu}(\mathrm{ADF})$ & $-5.454^{* * *}$ & (0) & $-4.321^{* * *}$ & (1) & $-11.01^{* * *}$ & (2) & $-6.29^{* * *}$ & (0) \\
\hline$\tau(\mathrm{ADF})$ & $-5.365^{* * *}$ & (0) & $-3.221^{* * *}$ & (1) & $-11.13^{* * *}$ & (2) & $-3.79^{* * *}$ & (0) \\
\hline$\tau_{\mathrm{T}}(\mathrm{PP})$ & $-6.009^{* * *}$ & (3) & $-6.425^{* * *}$ & (6) & $-11.21^{* * *}$ & (4) & $-6.25^{* * *}$ & (5) \\
\hline$\tau_{\mu}(\mathrm{PP})$ & $-5.630^{* * *}$ & (3) & $-3.522^{* *}$ & (1) & $-11.27^{* * *}$ & (4) & $-6.29^{* * *}$ & (3) \\
\hline$\tau(\mathrm{PP})$ & $-5.563^{* * *}$ & (3) & $-1.756^{*}$ & (5) & $-11.42^{* * *}$ & (4) & $-3.80^{* * *}$ & (3) \\
\hline
\end{tabular}

Note: SE represents school enrollment; LE is the life expectancy; FDI is the foreign direct investment; GN is the gross national income. $\tau_{T}$ stands for the general model with a drift and trend; $\tau_{\mu}$ is the model with a drift but without trend; $\tau$ is the model without drift and trend. Numbers in parentheses show optimum lag levels. $*, * *, * * *$ represents the rejection of the null hypothesis at $10 \%, 5 \%$ and $1 \%$ level of alpha, respectively.

Table 2 presents the results of the Johansen (1988) cointegration test for the three different models used in the study.

Table 2. Johansen (1988) Cointegration Test Results

\begin{tabular}{lrrrr}
\hline $\begin{array}{l}\text { Hypothesized } \\
\text { No of CE(s) }\end{array}$ & $\begin{array}{c}\text { Eigen } \\
\text { Value }\end{array}$ & $\begin{array}{l}\text { Trace } \\
\text { Statistic }\end{array}$ & $\begin{array}{l}\text { 5\% Critical } \\
\text { Value }\end{array}$ & \multicolumn{2}{l}{$\begin{array}{l}\text { 1\% Critical } \\
\text { Value }\end{array}$} \\
\hline Model 1. InSE=f (InFDI) & & & & \\
None** & 0.57 & 41.80 & 19.96 & 24.60 \\
At most 1 & 0.16 & 7.11 & 9.24 & 12.94 \\
Model 2. InLE=f (InFDI) & & & & \\
None** & 0.49 & 32.68 & 19.96 & 24.60 \\
At most 1 & 0.14 & 6.18 & 9.24 & 12.94 \\
Model 3. InGNI=f(InFDI) & & & & \\
None** & 0.47 & 30.72 & 19.96 & 24.6 \\
At most 1 & 0.11 & 4.98 & 9.24 & 12.97 \\
\hline Note: ** stands for the rejection of the null hypothesis at 1\% level of significance.
\end{tabular}

Johansen's (1988) cointegration test results confirm the long-run equilibrium relationship in model 1 , model 2 and model 3 , respectively. The null hypothesis of there is no cointegrating equation can be rejected at $1 \%$ level of significance in three of the models where the dependent variables are InSE, InLE and InGNI for the models 1, 2, and 3.

After revealing the long-run equilibrium relationship between variables, long-run coefficients are estimated by the DOLS approach separately for model 1 , model 2 , and model 3 . Table 3indicates the results of DOLS estimations for models 1,2 , and 3 , respectively. 
Table 3 indicates that FDI has an inelastic and statistically significant impact on school enrollment, which means that when FDI increases by $1 \%$, school enrollment in Nigeria increases by $0.829 \%$ in the long run. Results of the DOLS estimation for model 1 report the positive contribution of FDI on school enrollment.

Table 3. Estimation of Long-run Coefficients by DOLS approach

\begin{tabular}{|c|c|c|c|c|c|c|c|c|}
\hline \multirow{2}{*}{$\begin{array}{l}\text { Dependent } \\
\text { Variable }\end{array}$} & \multicolumn{3}{|c|}{ Regressors } & \multirow[b]{2}{*}{ Trend $^{2}$} & \multirow[b]{2}{*}{$\begin{array}{c}\text { R- } \\
\text { squared }\end{array}$} & \multirow[b]{2}{*}{$\begin{array}{c}\text { S.E. of } \\
\text { Regr }\end{array}$} & \multirow[b]{2}{*}{$\begin{array}{l}\text { D-W } \\
\text { stat. }\end{array}$} & \multirow[b]{2}{*}{$\begin{array}{l}\text { Long-run } \\
\text { Variance }\end{array}$} \\
\hline & InFDI & Constant & Trend & & & & & \\
\hline InSE & $\begin{array}{l}0.829 * \\
(0.000)\end{array}$ & $\begin{array}{c}5.906 * \\
(0.000)\end{array}$ & $\begin{array}{r}-0.187^{*} \\
(0.000)\end{array}$ & $\begin{array}{l}0.003^{*} \\
(0.001)\end{array}$ & 0.909 & 0.049 & 2.125 & 0.001 \\
\hline InLE & $\begin{array}{r}-0.059 * \\
(0.000)\end{array}$ & $\begin{array}{c}3.796 * \\
(0.000)\end{array}$ & $\begin{array}{l}0.004^{*} \\
(0.000)\end{array}$ & - & 0.999 & 0.001 & 2.163 & $2.78 \mathrm{E}-07$ \\
\hline InGNI & $\begin{array}{l}0.851^{*} \\
(0.000)\end{array}$ & $\begin{array}{l}5.767^{*} \\
(0.000)\end{array}$ & $\begin{array}{r}0.043 \\
(0.254)\end{array}$ & $\begin{array}{l}0.002^{*} \\
(0.000)\end{array}$ & 0.994 & 0.195 & 1.533 & 0.044 \\
\hline
\end{tabular}

Note: Optimum lag length is selected by Schwarz information criteria and long-run covariance is estimated by Bartlett Kernel and Newey-West fixed bandwidth, which is 3 . Numbers in parentheses show prob. values. ${ }^{*}$ denotes the significance level of $1 \%$.

Model 2 suggests that FDI has an inelastic, negative, and statistically significant effect on life expectancy at birth in Nigeria. A 1\% increase in FDI inflows decreases the life expectancy at birth, which is a proxy for public health. In addition, the long-run impact of FDI on GNI is estimated by model 3 which reveals that FDI has a positive, inelastic, and statistically significant effect on GNI, which means that a $1 \%$ increase in FDI leads to an increase in GNI by $0.851 \%$. To sum up, FDI has a positive contribution on education and income in Nigeria, while it has a negative effect on public health, according to the DOLS estimates.

Table 4. Toda Yamamoto (1995) Causality Test Results

\begin{tabular}{lcc}
\hline Hypothesis & Chi-square P-value & Decision \\
\hline InFDI does not cause InLE & 0.092 & $\begin{array}{l}\text { Reject } \\
\text { Reject }\end{array}$ \\
InLE does not cause InFDI & 0.006 & Fail to Reject \\
InFDI does not cause InSE & 0.799 & Fail to Reject \\
InSE does not cause InFDI & 0.691 & $\begin{array}{r}\text { Reject } \\
\text { Fail to Reject }\end{array}$ \\
InFDI does not cause InGNI & 0.010 & \\
\hline InGNI does not cause InFDI & 0.232 & \\
\end{tabular}

Notes: 10,000 simulations are used in order to calculate bootstrapped critical values. HJC criteria is used for the optimum lag length selection.

Directions of the long-run relationship between variables are estimated by the Toda Yamamoto (1995) causality test, and the results are reported in Table 4. There is a bidirectional relationship between life expectancy at birth and FDI, which means when there is a change in FDI, there is a change in life expectancy at birth and vice versa. Moreover, a unidirectional relationship is observed between the variables of FDI and GNI that runs from FDI to GNI. The unidirectional causal relationship between FDI and GNI reveals that GNI in Nigeria is FDI driven. Lastly, no causal relationship is observed between the variables of FDI and SE. 


\section{Conclusion}

The study investigates the long-run impact of FDI on several dimensions of human development for the period of 1972-2013. The long-run equilibrium relationship is confirmed by the Johansen (1988) cointegration test under three models using different measures of human development as regressors. Longrun coefficients of models are estimated by the DOLS approach. Results of DOLS estimates indicate FDI has a positive, inelastic, and statistically significant impact on school enrollment and GNI, while it has an inelastic, negative, and statistically significant impact on life expectancy at birth in the long run. The positive impact of FDI on school enrollment and GNI shows the importance of foreign investments to the host country; that is to say, FDI contributes to the educational development and income of the host country. By contrast, the negative impact of FDI on life expectancy, which is used as a proxy for public health, is a sign of increased competitiveness in the country. Increased competitiveness, to which FDI contributes, leads to work stress and economic insecurity, which cause deterioration of public health (Herzer \& Nunnenkamp, 2012). The harmful effects of work stress and economic insecurity are documented in several studies (Ferrie et al., 1995, 2002; Rugulies et al., 2008).

The long-run causal relationships between variables are investigated by the Toda-Yamamoto (1995) causality test. Test results indicate a bidirectional causal relationship between FDI and life expectancy at birth. The bidirectional relationship between FDI and LE reveals that FDI Granger causes public health variable, and public health Granger causes FDI in Nigeria. FDI may cause a deterioration of public health by the existence of introducing FDI-induced competitiveness and insecurity (Herzer \&Nagel, 2015). In response, a worsening public health causes a drop in FDI inflows. A change in public health variable causes changes in FDI inflows because public health is a component of human capital. Health in human capital increases productivity and attracts foreign investors (Alsan et al., 2006). Moreover, there is a unidirectional relationship running from FDI to GNI of the Nigerian economy, which indicates that any changes in FDI lead to a change in income for Nigeria. Causality running from FDI to GNI reveals that the income of Nigeria is FDI-driven, which emphasizes the importance of drawing the attention of foreign investors to the country.

The striking message our empirical findings conveys is that the effect of FDI on the HDI is a complicated issue, so to obtain optimum results policy-makers should be aware of and take into account the pros and cons of FDI inflows on several aspects of human development. Our results show that on the one hand, there is a positive effect of FDI on income and educational development, which means to attract foreign investors should be a priority for the Nigerian policy-makers. On the other hand, DOLS estimate reveals a negative effect of FDI on life expectancy in Nigeria as a result of FDI-induced competitiveness and insecurity. This finding puts forwards the idea that FDI is not a black or white process and policymakers should implement remedies to protect public health while trying to attract foreign investors to the country. For example, government spending on social insurance that compensates workers could be increased to reduce economic insecurity to reasonable levels. Even though data of Nigeria is employed in our analysis, we believe that our findings could serve as a guide for other developing countries policymakers to develop better policies to attract FDI without letting people suffer from the possible negative consequences of FDI.

\section{End Notes}

1. For other early important academic contributions, please see Hymer (1960) and Kindleberger (1969).

2. For some early studies, see: Rothgeb (1984), Sharma (1986), Doraisami \& Leng (1995), Dixon et al. (1996)

3. Nevertheless, a significant portion of the studies claim that FDI positively affects human development, although there are also many studies that suggest otherwise (see, Reiter \& Steensma, 2010;Azman-Saini, Baharumshah \& Law, 2010).

4. Refer to Kremers et al. (1992) and Gonzalo (1994) for their views about problems arising from the Engel and Granger (1987) tests as compared the approach of Johansen and Juselius (1990). 


\section{References}

Acemoglu, D., Johnson, S., \& Robinson, J. (2005). Institutions as the fundamental cause of long-run growth. In: Aghion, P., \& Durlauf, S. (Eds.), Handbook of Economic Growth. Elsevier, North Holland, pp. 385-472

Agosin, M. R., \& Machado, R. (2005). Foreign investment in developing countries: Does it crowd in domestic investment? Oxford Development Studies, 33(2), 149-162.

Alfaro, L., Chanda, A,.Kalemli, S., \& Sayek, O.S. (2004). FDI and economic growth: The role of local financial markets. Journal of International Economics, 64(1), 89-112

Alsadiq, A. (2013). Outward foreign direct investment and domestic investment: The case of developing countries. IMF Working Paper No. 13/52

Alsan, M., Bloom, D. E., \& Canning, D. (2006). The effect of population health on foreign direct investment inflows to low-and middle-income countries. World Development, 34(4), 613-630.

Amighini, A. \& Sanfilippo, M. (2014). Impact of South-South FDI and trade on the export upgrading of African economies. World Development, 64, 1-17

Anand, S., \& Sen, A. (2000).Human development and economic sustainability. World Development, 28(12), $2029-2049$.

AnumMohdGhazali, N. (2010). Ownership structure, corporate governance and corporate performance in Malaysia. International Journal of Commerce and Management, 20(2), 109-119.

Arcelus, F. J., Sharma, B., \& Srinivasan, G. (2005). Foreign capital flows and the efficiency of the HDI dimensions. Global Economy Journal, 5(2), 1-12.

Azman-Saini W.N.W., Baharumshah A.Z., \& Law S.H. (2010). Foreign direct investment, economic freedom and economic growth: International evidence. Economic Modeling, 27, 1079-1089

Baharumshah, A. Z., \& Thanoon, M. A. M. (2006). Foreign capital flows and economic growth in East Asian countries. China Economic Review, 17(1), 70-83.

Belloumi, M. (2014). The relationship between trade, FDI and economic growth in Tunisia: An application of the autoregressive distributed lag model. Economic Systems, 38(2), 269-287.

Bruno, M., Ravallion, M., \& Squire, L. (1998). Equity and growth in developing countries: Old and new perspectives on the policy issues. Income distribution and high-quality growth, 117-146.

Buckley, P. J. (1985). A critical view of theories of the multinational enterprise. In P. J. Buckley, \& M. Casson (Eds.).The economic theory of multinational enterprise (pp. 1-19). London: Macmillan.

Chang, S. C. (2010). Estimating relationships among FDI inflow, domestic capital, and economic growth using the threshold error correction approach. Emerging Markets Finance \& Trade, 46(1), 6-15.

Chowdhury, A., \& Mavrotas, G. (2006). FDI and growth: What causes what? World Economy, 29(1), 9-19.

Corporate Nigeria, (2010). The Business, Trade and Investment Guide.

De Mello, L. R. (1999). Foreign direct investment-led growth: Evidence from time series and panel data. Oxford Economic Papers, 51(1), 133-151.

Dickey, D., \& Fuller, W. A. (1981). Likelihood ratio statistics for autoregressive time series with a unit root. Econometrica, 49, 1057-1072.

Didia, D., Freeman, P., Assad, J.C., \& Yuan, J. (2015). Foreign capital, domestic policy, and economic growth: The case of Nigeria. Journal of Applied Economics and Business Research JAEBR, 5(4), 233-244.

Dixon, W. J., \& Boswell, T. (1996). Dependency, disarticulation, and denominator effects: Another look at foreign capital penetration. American Journal of Sociology, 102 (2), 543-562.

Doraisami, A. (1995). Foreign direct investment and economic growth: some time series evidence of the Malaysian experience. Asian Economies, 24, 50-59.

Dostie, B., \& Jayaraman, R. (2006). Determinants of school enrollment in Indian villages. Economic Development and Cultural Change 54(2), 405-421

Durham, J. B. (2004). Absorptive capacity and the effects of foreign direct investment and equity foreign portfolio investment on economic growth. European Economic Review, 48(2), 285-306.

Dunning, J. H. (1979). Explaining changing patterns of international production: In support of the eclectic theory. Oxford Bulletin of Economics and Statistics, 41(4), 269-295.

Ferrie, J. E., Shipley, M. J., Stansfeld, S. A., \& Marmot, M. G. (2002). Effects of chronic job insecurity and change in job security on self-reported health, minor psychiatric morbidity, physiological measures, and health related 
behaviours in British civil servants: The Whitehall II study. Journal of Epidemiology and Community Health, 56(6), 450-454.

Ferrie, J. E., Shipley, M. J., Marmot, M. G., Stansfeld, S., \& Smith, G. D. (1995). Health effects of anticipation of job change and non-employment: Longitudinal data from the Whitehall II study. Bmj, 311(7015), 1264-1269.

Engle, R. F., \& Granger, C. W. J. (1987). Co-integration and error correction: Representation, estimation, and testing. Econometrica, 55, 251-276.

Ericsson, J., \& Irandoust, M. (2001). On the causality between foreign direct investment and output: A comparative study. International Trade Journal, 15, 1-26.

Escobar, A. (2000). Beyond the search for a paradigm? Post-development and beyond. Development, 43(4), 11-14.

Evans, K. (2002). Foreign portfolio and direct investment: Complementarity, differences, and integration, OCDE global forum on international investment: Attracting foreign direct investment for development, Shanghai, $5-6$ December.

Herzer, D., \& Nagel, K. (2015). The long-run and short-run effects of health aid on life expectancy. Applied Economics Letters, (ahead-of-print), 1-5.

Gohou, G., \& Soumaré, I. (2012). Does foreign direct investment reduce poverty in Africa and are there regional differences? World Development, 40(1), 75-95.

Gonzalo, J. (1994). Five alternative methods of estimating long-run equilibrium relationships. Journal of Econometrics, 60(1), 203-233.

Hacker, S., \& Hatemi-J, A. (2010). HHcte: GAUSS module to apply a bootstrap test for causality with endogenous lag order. Statistical Software Components.

Hansen, H., \& Rand, J. (2006).On the causal links between FDI and growth in developing countries. The World Economy, 29, 21-41.

Hatemi-J, A. (2008). Tests for cointegration with two unknown regime shifts with an application to financial market integration. Empirical Economics, 35(3), 497-505.

Huang, R. D., \& Shiu, C. Y. (2009). Local effects of foreign ownership in an emerging financial market: Evidence from qualified foreign institutional investors in Taiwan. Financial Management, 38(3), 567-602.

Hymer, S. H. (1960). The international operations of national firms: a study of foreign direct investment. Cambridge, MA: The MIT Press (A 1960 doctoral thesis).

Iamsiraroj, S., \& Ulubasoglu, M. A. (2015). Foreign direct investment and economic growth: A real relationship or wishful thinking? Economic Modelling, 51, 200-213.

Imoudu, E.C. (2012). The impact of foreign direct investment on Nigeria's economic growth; 1980-2009: Evidence from the Johansen's cointegration approach. International Journal of Business and Social Science, 3(6), 122-34.

Inekwe, J.N. (2013). FDI, employment and economic growth in Nigeria. African Development Review, 25, $421-433$.

Johansen, S., \& Juselius, K. (1990). Maximum likelihood estimation and inference on co-Integration with application to the demand for money. Oxford Bulletin of Economics and Statistics, 52, 169-209.

Johansen, S. (1988). Statistical analysis of co-integration vectors. Journal of Economic Dynamics and Control, 12, 231254.

Kemeni, T. (2010). Does foreign direct investment drive technological upgrading? World Development, 38(11), 15431554

Khawar, M. (2003).Productivity and foreign direct investment-evidence from Mexico. Journal of Economic Studies, 30(1), 66-76.

Kindleberger, C. P. (1969). American business abroad. New Haven: Yale University Press.

Kremers, J. J., Ericsson, N. R., \& Dolado, J. J. (1992).The power of cointegration tests. Oxford Bulletin of Economics and Statistics, 54(3), 325-348.

Krugman, P. R. (1995). Peddling prosperity: Economic sense and nonsense in the age of diminished expectations. WW Norton \& Company.

Lall, S., \& Narula, R. (2004). Foreign direct investment and its role in economic development: Do we need a new agenda? The European Journal of Development Research, 16(3), 447-464.

$\mathrm{Li}, \mathrm{X}$., \& Liu, X. (2005). Foreign direct investment and economic growth: An increasingly endogenous relationship. World Development, 33, 393-407. 
Neto, D.G, \& Veiga, F.J. (2013). Financial globalization, convergence and growth: The role of foreign direct investment. Journal of International Money and Finance, 37, 161-186

Neto, P., Brandão, A., \& Cerqueira, A. (2008). The impact of FDI, cross-border mergers and acquisitions, and greenfield investments on economic growth. The IUP Journal of Business Strategy, 24-44.

OECD (2007). International Development Statistics.

Omri, A., Nguyen, D.K, \& Rault, C. (2014). Causal interactions between CO2 emissions, FDI, and economic growth: Evidence from dynamic simultaneous-equation models. Economic Modelling, 42, 382-389.

Omri, A. (2014). The nexus among foreign investment, domestic capital and economic growth: Empirical evidence from the MENA region. Research in Economics, 68(3), 257-263.

Osemwengie, P. K., \& Sede, P. I. (2013). Foreign direct investment and poverty reduction in Nigeria: Evidence from cointegration and error correction modeling methodology. Peace and Environment Africa: Special Edition, 9, 93109.

Phillips, P., \& Perron, P. (1988).Testing for a unit root in time series regression. Biometrica, 75, 335-346.

Porter, M. E. (1990). The competitive advantage of nations. London: Macmillan.

Pyatt, G. (1987). Measuring welfare, poverty and inequality. The Economic Journal, 97(386), 459-467.

Ranis, G., Stewart, F., \& Ramirez, A. (2000). Economic growth and human development. World Development, 28(2), 197219.

Ravallion, M. (2007). Economic growth and poverty reduction: Do poor countries need to worry about inequality? 2020 focus brief on the world's poor and hungry people. Washington, DC: International Food Policy Research Institute.

ReigerS.L., \& Steensma H.K. (2010). Human development and foreign direct investment in developing countries: The influence of FDI policy and corruption. World Development, 38(12), 1678-1691.

Rothgeb, J. M. (1984). The effects of foreign investment on overall and sectoral growth in third world states. Journal of Peace Research, 21(1), 5-14.

Rugulies, R., Aust, B., Burr, H., \& Bültmann, U. (2008).Job insecurity, chances on the labour market and decline in selfrated health in a representative sample of the Danish workforce. Journal of Epidemiology and Community Health, 62(3), 245-250.

Salako, H.A., \& Adebusuyi, B.S. (2001). Determinants of foreign direct investment: Evidence from establishment data. Journal of Development Studies, 36(1), 53-73.

Sede, P.I., \& Ohemeng W. (2015). Socio-economic determinants of life expectancy in Nigeria (1980-2011). Health Econ Rev., 5(2).

Sede, P.I., \& Ohemeng, W. (2012). An empirical assessment of the technical efficiency in some selected hospitals in Nigeria. J Bus Res. 6, 14-43.

Sen, A. (1998). Mortality as an indicator of economic success and failure. The Economic Journal, 108(446), 1-25

Sen, A. (1997). Editorial: Human capital and human capability. World Development, 25(12), 1959-1961.

Sen, A. (1995). Gender inequality and theories of justice. In M. Nussbaum and J. Glover (Eds.), Women, Culture, and Development, Clarendon Press, Oxford, 259-273.

Sen, A. (1992). Inequality reexamined. Oxford University Press.

Sen, A. (1987). The standard of living: lecture I, concepts and critiques. Tanner Lectures, Cambridge University Press, Cambridge.

Shaikh, F. M. (2010). Causality relationship between foreign direct investment, trade and economic growth in Pakistan. In International Business Research (Vol. 1, pp. 11-18). Harvard Business School.

Sharma, B., \& Gani, A. (2004).The effects of foreign direct investment on human development. Global Economy Journal, $4(2), 1-18$

Sharma, B. (1986). Foreign capital and economic growth of developing countries Debt vs. Equity Studies in Comparative International Development (SCID), 21(1), 60-70.

Stiglitz, J. E. (2006). Making globalization work. New York: W.W. Norton and Company.

Stock, J. H., \& Watson, M. W. (1993). A simple estimator of cointegrating vectors in higher order integrated systems. Econometrica: Journal of the Econometric Society, 783-820.

Streeten, P. (1999). Components of a future development strategy. Finance \& Development, 36(4), 30-33. 
Sun, M., \& He, Q. (2014). Does foreign direct investment promote human capital accumulation? The role of gradual financial liberalization. Emerging Markets Finance and Trade, 50(4), 163-175.

Toda, H. Y., \& Yamamoto, T. (1995). Statistical inference in vector autoregressions with possibly integrated processes. Journal of Econometrics, 66(1), 225-250.

Umoh, O., Jacob, A., \& Chuku, C. (2012). Foreign direct investment and economic growth in Nigeria: An analysis of the endogenous effects. Current Research Journal of Economic Theory, 4(3), 53-66.

United Nations Development Program (1999). Human Development Report 1999, Oxford University Press, Oxford.

United Nations Conference on Trade and Development (UNCTAD) (2011). Foreign direct investment in LDCS: Lessons learned from the decade 2001-2010 and the way forward.

World Bank development indicators (2015). Retrieved from: http://databank.worldbank.org (Last access: September 2017).

Vernon, R. (1966). International investment and international trade in the product cycle. Quarterly Journal of Economics, 80(2), 190-207. 
This Page Intentionally Left Blank 